\title{
PHENOLS AND NITROPHENOLS AS TROPOSPHERIC POLLUTANTS : EMISSIONS FROM AUTOMOBILE EXHAUSTS AND PHASE TRANSFER IN THE ATMOSPHERE
}

\author{
J. TREMPa), P. MATTREL ${ }^{\text {b) }}$, S. FINGLER ${ }^{\text {c) }}$ and W. GIGER \\ EAWAG \\ Swiss Federal Institute for Water Resources and Water Pollution Control \\ $\mathrm{CH}-8600$ Dübendorf, Switzerland
}

a) present address : Environmental Protection Agency of Canton Basel-Landschaft $\mathrm{CH}-4410$ Liestal, Switzerland

b) Swiss Federal Laboratories for Material Testing and Research $\mathrm{CH}-8600$ Dübendorf, Switzerland

c) Institute for Medical Research and Occupational Health 41001 Zagreb, Croatia

\begin{abstract}
Motor exhaust gas from an automobile motor, operated under stationary conditions with unleaded gasoline, was sampled with two different impinger bath methods. The samples were analyzed by gas chromatography/mass spectrometry (GC/MS) for phenol, cresols and nitrated phenols. Phenol and cresols were measured in the range of $80-220 \mathrm{nmol} / \mathrm{L}$ of exhaust gas from a noncatalyst engine, and nitrated phenols were found in the range of $9-36 \mathrm{nmol} / \mathrm{L}$. A large reduction of total phenols down to $7 \%$ and less was observed when the engine was operated with a regulated three-way catalytic converter. The result of this study shows that exhaust gas sampling of phenols with alkaline aqueous impinger solutions leads to an underestimation of phenol emissions, since phenols are not stable under high-pH conditions.

In order to better assess the environmental fate of nitrated phenols, laboratory experiments were conducted to measure the Henry's law constants of a series of nitrated phenols. For that purpose an apparatus for dynamic determination of the Henry's law constants was constructed and successfully used. Special emphasis was put on temperature dependence of the Henry's law constants.
\end{abstract}

\section{Introduction}

Nitrogen oxides play a central role in the chemistry of the atmosphere. These nitrogenous species are also involved in transformation reactions with organic compounds as reaction partners. Among the well-known products of such transformations are nitrated PAHs and peroxyacetylnitrates.

Water, Air, and Soil Pollution 68: 113-123, 1993.

(c) 1993 Kluwer Academic Publishers. Printed in the Netherlands. 
Beside nitro-PAHs and organic nitrates, another class of organic "nitrocompounds" has to be considered to play a significant role as atmospheric pollutants of environmental concern: nitrated phenols. Like other classes of air pollutants, nitrated phenols participate in the complex chemical and physical processes which dominate their behavior and fate in the troposphere.

Phenol, cresols and nitrated phenols have been found in atmospheric air in the $\mathrm{ng} / \mathrm{m}^{3}$ range (Herterich \& Herrmann, 1990; Leuenberger et al., 1985) and in different condensed phases in the atmosphere (rain, fog and snow) up to about $100 \mu \mathrm{g} / \mathrm{L}$ (Leuenberger et al., 1988; Kawamura \& Kaplan, 1986; Rippen et al., 1987; Alber et al., 1989; Tremp, 1991). It has been shown in smog chamber experiments that nitrated phenols can be formed photochemically by reactions of precursor compounds (benzene, toluene, phenol and cresols) with hydroxyl radicals and nitrogen oxides (Atkinson et al., 1980; Leone \& Seinfeld, 1985; Grosjean, 1984). Some dinitrophenols, e. g. 6-methyl-2,4-dinitrophenol (DNOC) and 2,4-dinitro-6-sec-butylphenol (Dinoseb) are used as pesticides in agriculture.

Apart from these possible origins of nitrated phenols in the atmosphere, direct formation in combustion processes of fossil fuels could be another source of nitrated phenols in the atmosphere. Phenol, cresols and nitrated phenols are among the most important classes of toxic anthropogenic organic compounds in the atmosphere (Leuenberger et al., 1988). In contrast to the knowledge about PAHs and nitro-PAHs there is a lack of data on motor vehicle emissions of nitrated phenols. Only Nojima et al. (1983) reported the identification of nitrophenols in exhaust gas of gasoline- and Diesel-engines.

The goal of our first study was the identification and quantitation of individual nitrated phenols as a function of motor operation conditions, with and without a regulated three-way catalytic converter (CAT) in order to have a rough estimate whether and to what extent nitrated phenols in the atmosphere are primary emissions from motor vehicles.

Our second study addresses the transfer processes of nitrophenols between air and water bodies such as cloud-, rain- or fog droplets. Under equilibrium conditions the distribution of nitrated phenols between these two phases is given by Henry's law:

$$
\begin{aligned}
& \mathrm{H}=\frac{\mathrm{y}_{\mathrm{i}} \cdot \mathrm{P}}{\mathrm{C}_{\mathrm{w}, \mathrm{i}}}=\frac{\mathrm{P}_{\mathrm{i}}}{\mathrm{c}_{\mathrm{w}, \mathrm{i}}} \quad\left[\mathrm{Pa} \cdot \mathrm{m}^{3} \cdot \mathrm{mol}^{-1}\right] \\
& \mathrm{y}_{\mathrm{i}}: \text { gas phase mole fraction of solute } \mathrm{i}[-] \\
& \mathrm{P}: \quad \text { pressure }[\mathrm{Pa}] \\
& \mathrm{P}_{\mathrm{i}}: \text { partial pressure of the solute } \mathrm{i}[\mathrm{Pa}] \\
& \mathrm{c}_{\mathrm{w}, \mathrm{i}}: \text { concentration of solute } \mathrm{i} \text { in water }\left[\mathrm{mol} \cdot \mathrm{m}^{-3}\right]
\end{aligned}
$$


For a variety of nonpolar organic compounds it has been stated by many authors, that Henry's law constants can be approximately calculated by the ratio of the saturation vapor pressure of the pure compound and the aqueous solubility (Mackay \& Shiu, 1981) $\quad \mathrm{H}=\frac{\mathrm{p}^{0}}{\mathrm{C}_{\mathrm{w}}^{\text {sat }}}$

Using the aqueous solubility $\left(\mathrm{C}_{\mathrm{w}}^{\text {sat }}\right)$ and the vapor pressure $\left(\mathrm{P}^{0}\right)$ for estimating Henry's law constants, it is assumed that the activity coefficient of the solute in the aqueous phase is constant over the concentration range of interest. It is well known, that, within the compound class of nitrated phenols, solute-solute interactions can significantly affect aqueous solubility (Schwarzenbach et al., 1988). Therefore it is important to have precisely measured data for validation of the calculated Henry's law constants before using them in modelling environmental processes.

\section{Experimental}

\subsection{NITRATED PHENOLS IN MOTOR EXHAUSTS}

Motor exhausts of an Audi-80 motor, operated under stationary conditions with unleaded gasoline (Table 1), has been sampled with two different impinger-methods. 3 impingers in series, containing either alkaline or buffered $\mathrm{pH} 2$ aqueous solutions were used to control breakthrough. By adding deuterated phenols, the formation of additional nitrophenols in the sampling system was investigated. The samples have been analyzed with GC/MS.

TABLE 1. Motor operating conditions for the two selected loads.

\begin{tabular}{ccccccc}
\hline $\begin{array}{c}\text { motor } \\
\text { operation } \\
\text { point }\end{array}$ & $\begin{array}{c}\text { rotation } \\
\text { speed }\end{array}$ & nominal power load & fuel consumption & exhaust gas production ${ }^{\mathrm{a}}$ \\
& $\mathrm{rpm}$ & $\mathrm{kW}$ & $\begin{array}{r}\% \text { full } \\
\text { power }^{\mathrm{b}}\end{array}$ & $\mathrm{kg} / \mathrm{h}$ & $\mathrm{kg} / \mathrm{h}$ & $\mathrm{m}^{3} / \mathrm{h}$ \\
\hline $\mathrm{A}$ & 2900 & 15.8 & 36 & 4.97 & 69.6 & 53.9 \\
$\mathrm{~B}$ & 4150 & 46.7 & 74 & 11.91 & 174 & 134.5 \\
\hline
\end{tabular}

a: normal temperature- and pressure conditions $1000 \mathrm{mbar}, 20^{\circ} \mathrm{C}$

b: $100 \%=$ maximum load of the motor at the corresponding rotation speed 
Twelve phenols and nitrated phenols could be identified in the impinger samples of the exhausts: phenol, 2-methylphenol (o-cresol), 3- and 4-methylphenol ( $m-/ p$-cresol), 2-nitrophenol, 4-nitrophenol, 3- and 6-methyl2-nitrophenol, 4-methyl-2-nitrophenol, 5-methyl-2-nitrophenol, 3-methyl4-nitrophenol, 2-methyl-4-nitrophenol, 2,4-dinitrophenol, and 6-methyl2,4-dinitrophenol (DNOC). In all experiments with phosphate buffer as absorber solution, phenol and $m-/ p$-cresol showed the highest concentrations of all nitrated phenols and $o$-cresol present in these samples. The corresponding data of the $\mathrm{NaOH}$ impinger solution experiments are much more inhomogeneous. Compared to the phosphate buffer sampling under the same motor conditions (without CAT), these experiments showed significantly smaller concentrations of phenols and cresols, both absolutely and relatively to the nitrated phenols. The reason for these differences is thought to be the instability of phenols in an aqueous medium at higher $\mathrm{pH}$ (Figure 1).

The CAT reduced the emitted phenols to about $92 \%$ at high motor load (4150 r.p.m.) and to about $98 \%$ at normal motor load (2900 r.p.m.). The sum of phenol emissions with CAT is slightly higher (1.7 times) at high load. In contrast, without CAT, normal load conditions gave 2.9 times higher total phenol emissions, compared to the high motor load.

Using the CAT, a significant smaller part of the total phenols can be attributed to nitrated species (less than 1\%) compared to the same motor operating conditions without CAT $(10 \%-15 \%)$. The differences between the two motor loads are not significant.

About $40 \%$ of the total cresols were emitted as nitrated cresols when no CAT has been used, whereas it have been less than $2 \%$ with CAT. Nitrated phenols contributed to total phenols only to about $3 \%$ without CAT and $0.5 \%$ or less with CAT.

For all motor operating conditions, 4-methyl-2-nitrophenol, 3- and 6-methyl2-nitrophenol, 4-nitrophenol, and 2-nitrophenol belong to the most abundant nitrated phenol species, which could be found. The dinitrophenols, i.e. 2,4-dinitrophenol, and 6-methyl-2,4-dinitrophenol (DNOC) show the smallest concentrations, usually $<10 \mathrm{ng} / \mathrm{L}$ exhausts. There was no significant change in the relative distribution of the individual species when changing the motor load conditions.

Good linear correlations $\left(\mathrm{R}^{2} \geq 0.998\right)$ have been observed when plotting the concentration of total hydrocarbons against the concentrations of the total phenols and the sum of the concentrations of nitrated phenols, respectively. The CAT eliminated polar organic compounds like phenols and nitrated phenols in the exhaus more effectively than less polar or more reduced organics, measured as total hydrocarbons.

Deuterated phenols have been added in excess compared to the trapped phenol species. Based on this fact and on the data about the portions of the individual d-phenol species transformed to nitrated products it is assumed, that only a small part of the phenol was nitrated in solution. 


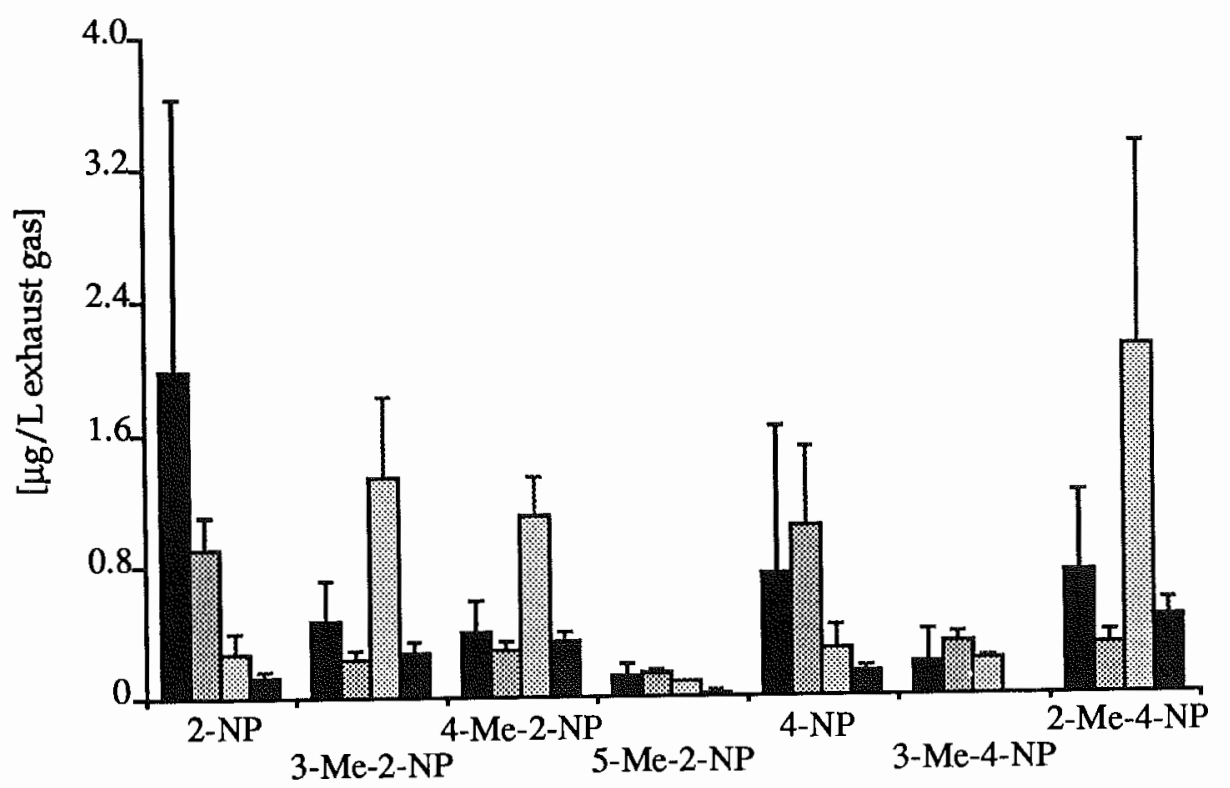

$0.5 \mathrm{~N} \mathrm{NaOH}$ impinger solution, without d-phenols, 2900 r. p. m.

$\square 0.5 \mathrm{~N} \mathrm{NaOH}$ impinger solution, without d-phenols, 4150 r. p. $\mathrm{m}$.

[s] 0.1M phosphate buffer impinger solution $\mathrm{pH} 2$, d-phenols added, 2900 r. p. $\mathrm{m}$.

2 $0.1 \mathrm{M}$ phosphate buffer impinger solution $\mathrm{pH} 2$, d-phenols added, 4150 r. p. m.

Figure 1. Measured emission of nitrated phenols in motor exhausts without CAT, using different impinger solutions and motor operating conditions. Mean concentrations in $[\mu \mathrm{g} / \mathrm{L}$ exhausts] with standard deviations.

For the nitrated methylphenols however it cannot be excluded, that a significant portion originates from a sampling artifact. It is assumed that this artifact contributes up to one third to the measured concentrations of nitrated cresols.

\subsection{DETERMINATION OF HENRY'S LAW CONSTANTS}

Henry's law constants of 19 nitrated phenols have been determined by a stripping column technique (Tremp, 1992). The set of compounds includes all nitrated phenol species that are the most important ones in the tropospheric air in terms of concentration and ecotoxicological significance. Some additional substituted nitrophenols have been included in this study to get insight in structure-based differences of the data. Henry's law constants of nitrated 
TABLE 2. Comparison of measured with calculated Henry's law constants (H) of phenol, cresols, nitrophenols and substituted nitrophenols

\begin{tabular}{|c|c|c|c|c|c|c|}
\hline \multirow{2}{*}{ compound } & measured & measured & measured & calculated * & measured & calculated * \\
\hline & $\begin{array}{c}\mathrm{H} ; 293 \mathrm{~K} \\
{\left[\mathrm{~m}^{3} \mathrm{~Pa} / \mathrm{mol}\right]}\end{array}$ & $\begin{array}{c}-\log (\mathrm{H}) ; 293 \mathrm{~K} \\
{\left[\mathrm{~m}^{3} \mathrm{~Pa} / \mathrm{mol}\right]}\end{array}$ & $\begin{array}{c}-\log (\mathrm{H}) ; 293 \mathrm{~K} \\
{[\mathrm{~Pa} / \mathrm{M}]}\end{array}$ & $\begin{array}{c}-\log (\mathrm{H}) ; 293 \mathrm{~K} \\
{[\mathrm{~Pa} / \mathrm{M}]}\end{array}$ & $\begin{array}{c}-\log (\mathrm{H}) ; 303 \mathrm{~K} \\
{\left[\mathrm{c}_{\mathrm{a}} / \mathrm{c}_{\mathrm{W}}\right]}\end{array}$ & $\begin{array}{c}-\log (\mathrm{H}) ; 293 \mathrm{~K} \\
{\left[\mathrm{c}_{\mathrm{a}} / \mathrm{C}_{\mathrm{W}}\right]}\end{array}$ \\
\hline 2-nitrophenol & $1.3 \mathrm{E}+00$ & -0.13 & -3.1 & -3.1 & 3.0 & 3.3 \\
\hline 4-nitophenol & $1.3 \mathrm{E}-03$ & 2.9 & -0.12 & -0.53 & 5.2 & 5.9 \\
\hline 3-methyl-2-nitrophenol & $3.1 \mathrm{E}-01$ & 0.50 & -2.5 & -2.6 & 3.7 & 3.8 \\
\hline 4-methyl-2-nitrophenol & $1.5 \mathrm{E}+00$ & -0.17 & -3.2 & -3.2 & 2.9 & 3.2 \\
\hline 5-methyl-2-nitrophenol & $1.3 \mathrm{E}+00$ & -0.13 & -3.1 & -3.2 & 3.0 & 3.2 \\
\hline 6-methyl-2-nitrophenol & $3.4 \mathrm{E}+00$ & -0.53 & -3.5 & - & 2.6 & - \\
\hline 2-nitro-4-sec-butylphenol & $9.7 \mathrm{E}+00$ & -0.99 & -4.0 & -3.6 & 2.2 & 2.8 \\
\hline 3-methyl-4-nitrophenol & $1.6 \mathrm{E}-03$ & 2.8 & -0.21 & - & 5.1 & - \\
\hline 2,4-dinitrophenol & $8.7 \mathrm{E}-03$ & 2.1 & -0.94 & -1.5 & 5.3 & 4.9 \\
\hline DNOC & $2.3 \mathrm{E}-02$ & 1.6 & -1.4 & -1.6 & 4.8 & 4.8 \\
\hline 4-methyl-2,6-dinitrophenol & $5.4 \mathrm{E}-03$ & 2.3 & -0.74 & - & 5.5 & 一 \\
\hline Dinoseb & $4.5 \mathrm{E}-01$ & 0.35 & -2.7 & - & 3.4 & - \\
\hline phenol & $6.5 \mathrm{E}-02$ & 1.2 & -1.8 & 一 & 4.4 & - \\
\hline o-cresol & $1.4 \mathrm{E}-01$ & 0.85 & -2.1 & - & 4.0 & - \\
\hline p-cresol & $7.5 \mathrm{E}-02$ & 1.1 & -1.9 & - & 4.3 & - \\
\hline 5-fluoro-2-nitrophenol & $2.0 \mathrm{E}+00$ & -0.29 & -3.3 & -2.2 & 2.8 & 4.2 \\
\hline 4-methoxy-2-nitrophenol & $1.9 \mathrm{E}-01$ & 0.73 & -2.3 & -3.6 & 3.8 & 2.7 \\
\hline
\end{tabular}

* from Schwarzenbach et al. (1988); calculated from vapor pressures of the subcooled liquid compound (estimated from GC-retention times) and the experimentally determined solubilities; $c_{\mathrm{a}}$ : concentration of the compound in the air; $c_{w}$ : concentration of the compound in the water 
phenols at $293 \mathrm{~K}$ cover a wide range of almost four orders of magnitude, between $1.3 \cdot 10^{-3}$ and $9.7 \mathrm{~m}^{3} \cdot \mathrm{Pa} \cdot \mathrm{mol}^{-1}$. Good agreement of measured Henry's law constants with calculated Henry's law data from aqueous solubility and vapor pressure has been found for nitro- and/or alkylsubsituted phenols.

Table 2 presents the Henry's law constants of phenol, cresols and nitrated phenols. Experimental data of this work and literature data are included. A very good agreement between measured and calculated $\mathrm{H}$ for 2-nitrophenol and the methyl-2-nitrophenols is obvious. Calculation from $\mathrm{P}^{0}(\mathrm{~L})$ and $\mathrm{C}_{\text {sat }}^{\mathrm{W}}(\mathrm{L})$ slightly underestimates $\mathrm{H}$ for 4-nitrophenol, 2,4-dinitro-, phenol, and DNOC. $\mathrm{H}$ of 2-nitro-4-sec-butylphenol is slightly overestimated, $\mathrm{H}$ of 5-fluoro-2-nitro-phenol is strongly overestimated by calculation. Calculation underestimates $\mathrm{H}$ of 4-methoxy-2-nitrophenol by more than one order of magnitude.2-nitrophenols have larger Henry's law constants than phenol, the cresols and the 4-nitrophenols. This is thought to be due to the formation of intramolecular hydrogen bonds which affects both, the vapor pressure (increase) and the aqueous solubility (decrease due to the competition of intramolecular- with the solute-water hydrogen bonds). The introduction of a hydrophobic substituent to the aromatic ring (2-nitro-4-secbutylphenol, Dinoseb) results in a considerable increase in $\mathrm{H}$ because of a large solubility reduction. A hydrophobic substituent gives a more significant contribution to an increase of $\mathrm{H}$ in the ortho position than in meta and para positions, may be because of the reduction of the hydrogen bonding capacity of the hydroxyl-proton. 4-nitrophenols exhibit by far higher aqueous solubilities and smaller vapor pressures than the corresponding 2-nitrophenols. This results in a remarkably smaller $H$ of 4-nitrophenols by 2 to 3 orders of magnitude, relative to 2 -nitrophenols.

Air concentrations of phenolic compounds during a fog event can be calculated when the following parameters are known: the volume ratio of air to condensed suspended fogwater $\left(\mathrm{V}_{\mathrm{air}} / \mathrm{V}_{\mathrm{water}}\right)$, the $\mathrm{pH}$ in fogwater, the acidity constant $\left(\mathrm{K}_{\mathrm{a}}\right)$ and the Henry's law constant $(\mathrm{H})$ of the phenol species.

The concentration in the interstitial air is given by equation

$$
c_{\text {air }}=\frac{\left(\frac{1}{f_{W}}-1\right) \cdot V_{\text {water }} \cdot c_{\text {water }}}{V_{\text {air }}}
$$


where

$\left.\mathrm{f}_{\mathrm{w}}=\frac{1}{1+\left(\frac{\mathrm{V}_{\text {air }}}{\mathrm{V}_{\text {water }}} \cdot \mathrm{D}_{\text {air }} / \text { water }\right.}\right) \quad$ and $\quad \mathrm{D}_{\text {air } / \text { water }}=\frac{\mathrm{H}_{\mathrm{C}}}{1+10\left(\mathrm{pH}-\mathrm{pK}_{\mathrm{a}}\right)}$

$\mathrm{H}_{\mathrm{C}}$ is the dimensionless Henry's law constant

Two examples of measured total phenols concentrations in fogwater $\left(c_{W}\right)$ and calculated concentrations of phenol species in interstitial air $\left(c_{a}\right)$ in sequential fog samples for the fog event of Oct.-17/18, 1988 are given in figure $2 b$. The corresponding curves of the liquid water content (LWC) and fogwater $\mathrm{pH}$ in the sequential samples of this fog event is depicted in figure 2a.

For phenol, the cresols and the mononitrophenols the curves of the fogwater- and the interstitial air concentration usually follow each other, i. e. their ratio remains rather constant. In contrast, a different behaviour can be observed for the dinitrophenols, where changes in the $\mathrm{pH}$ of the fogwater shift the equilibrium between the total concentration of the dinitrophenol species in the liquid water phase (neutral and deprotonated species) and the gas phase.

Figure 2a. Liquid water content (LWC) and $\mathrm{pH}$ values measured in subsequent fog samples during event Oct.-17/18, 1988

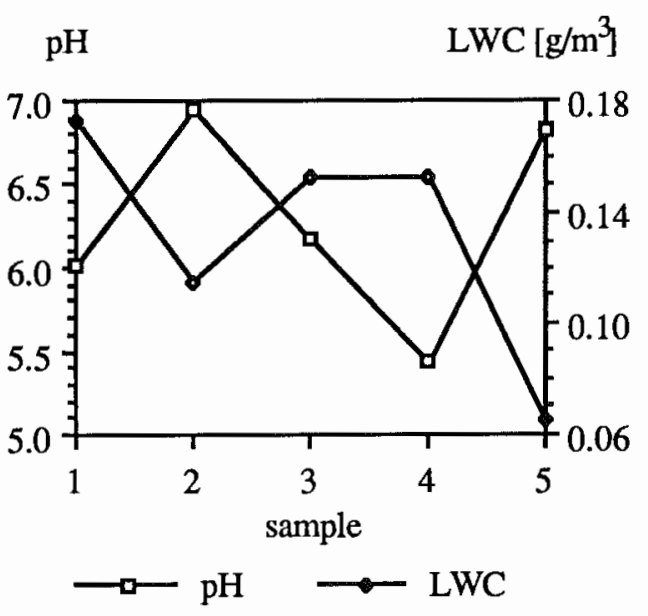


Figure 2b. Equilibrium distribution of selected nitrophenol species between the dissolved phase (fogwater) and the gaseous phase (intertitial air) in subsequent fog samples during the fog event of Nov.-17/18, 1988. Concentrations in interstitial air have been calculated.
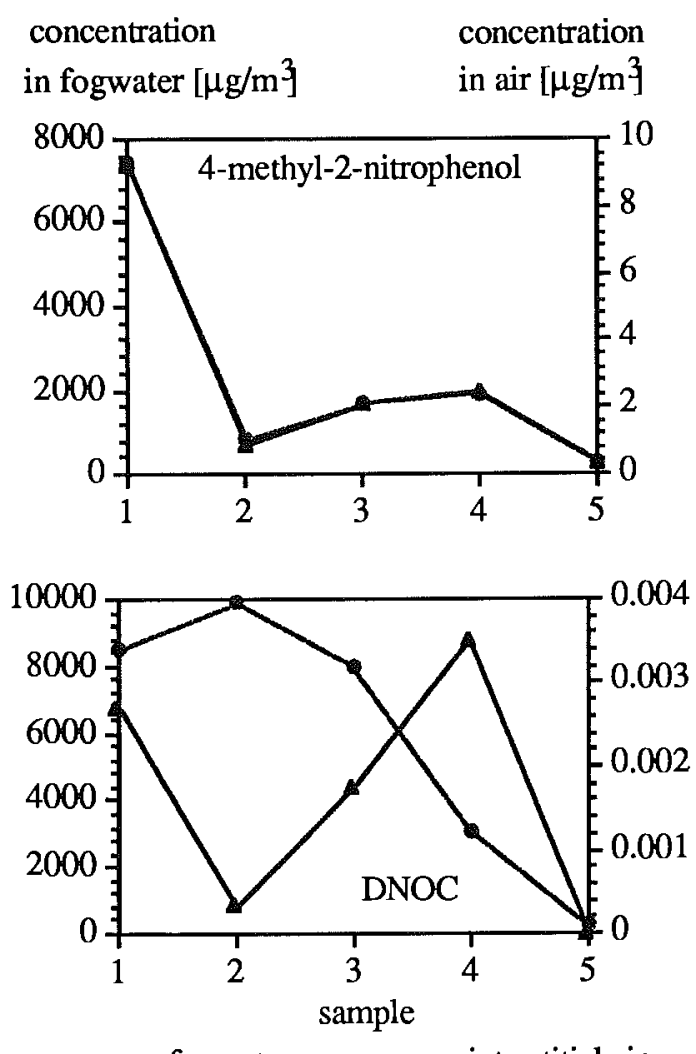

$\longrightarrow$ fogwater $\longrightarrow$ interstitial air

\section{Conclusions}

The experimental data of this work revealed that exhausts of Otto engines contribute as a direct source of nitrated phenols to their occurrence in the tropospheric air and as a consequence, in wet and dry deposition. More experimental work has to be done to get a reliable database for the estimation of the release of nitrophenols into the troposphere by different sources (Otto- and Diesel-engines, residential oil- and wood-burning, industrial incineration processes, etc.), compared to the photochemical formation of nitrated phenols in the atmosphere. 


\section{Acknowledgements}

We thank C. Schaffner for technical and instrumental assistance and for his many helpful comments, R. Ziegler for operating the motor, E. Molnar for correcting the manuscript, A. Paul for the permission to use the motor exhaust sampling system, A. Kerr and K. Hart for reviewing the manuscript.

This work was funded by the "WaBoLu" project of the Swiss Institute for Technology (ETH).

\section{References}

Alber, M., Böhm, H. B., Brodesser, J., Feltes, J., Levsen, K., and Schöler, H. F.: Determination of nitrophenols in rain and snow. Fresenius $Z$. Anal. Chem. 344, 540-545 (1989)

Atkinson, R., Carter, W. P. L., Darnal, K. R., Winer, A. M., Pitts, J. N. Jr.: A smog chamber and modelling study of the gas phase NOx-air photooxidation of toluene and the cresols. Int. J. Chem. Kin. 12, 779-836 (1980)

Atkinson, R.: Gas-phase tropospheric chemistry of organic compounds: a review. Atmos. Environ. 24A, 1-41 (1990)

Grosjean, D.: Atmospheric reactions of ortho cresols: gas phase and aerosol products Atmos. Environ. 18, 1641-1652 (1984)

Herterich R., Herrmann. R.: Comparing the distribution of nitrated phenols in the atmosphere of two German hill sites. Environ. Technol. 11, 961972 (1990)

Kawamura, K. and. Kaplan., I. R.: Biogenic and anthropogenic organic compounds in rain and snow samples collected in Southern California. Atmos. Environ. 20, 115-124 (1986)

Leone, J. A., Seinfeld, J. H.: Comparative analysis of chemical reaction mechanism for photochemical smog. Atmos. Environ. 19, 437-464 (1985)

Leuenberger, C., Czuczwa, J., und Giger, W.: Fortschrittsbericht "Lufthaushalt und Luftverschmutzung in der Schweiz". Teilprogramm 1 Art und Ausmaß von Luftverunreinigungen: Organische Verbindungen in Niederschlägen (1985)

Leuenberger, C., Czuczwa, J., Tremp, J., and Giger, W.: Nitrated phenols in rain: atmospheric occurence of phytotoxic pollutants. Chemosphere 17, 511-515 (1988)

Leuenberger, C., Ligocki, M. P., and Pankow, J. F.: Trace organic compounds in rain. 4. Identities, concentrations and scavenging mechanisms for phenol in urban air and rain. Environ. Sci. Technol. 19, 1053-1058 (1985)

Mackay D., Shiu W. Y.: A critical review of Henry's law constants for chemicals of environmental interest. J. Phys. Chem. Ref. Data 10, 1175-1199 (1981) 
Nojima K., Kawaguchi A., Ohia T., Kanno S., and Hirobe M.: Studies of photochemical reactions of air pollutants. X. Identification of nitrophenols in suspended particulates. Chem. Pharm. Bull. 31, 1047-51 (1983)

Rippen, G., Zietz, E., Frank, R., Knacker, T., and Kloepffer, W.: Do airborne nitrophenols contribute to forest decline? Environ. Technol. Lett. 8, 475482 (1987)

Schwarzenbach R. P., Stierli. R., Folsom B. R., and. Zeyer. J.: Compound properties relevant for assessing the environmental partitioning of nitrophenols. Environ. Sci. Technol. 22, 83-92 (1988)

Tremp J.: Sources and fate of nitrated phenols in the atmospheric environment. Ph. D. thesis (1992) 
